Bull. Egypt. Soc. Physiol. Sci. 36(2), 107-116

\author{
Bull. of Egyp. Soc. Physiol. Sci. \\ (Official Journal of Egyptian Society for Physiological Sciences) \\ (pISSN: 1110-0842; eISSN: 2356-9514)
}

\title{
Selenium Increases Testicular Steroidogenesis and Growth Factors Expression in Streptozotocin-induced Diabetic Rats
}

\author{
${ }^{1}$ Hoda M Moghazy, ${ }^{2}$ Aida A. Mahmoud, ${ }^{3}$ Muhammad M. A. Salman \\ ${ }^{1}$ Medical Physiology Department, Faculty of Medicine, Sohag University, Egypt. \\ ${ }^{2}$ Medical Biochemistry Department, Faculty of Medicine, Sohag University, Egypt. \\ ${ }^{3}$ Zoology Department, Faculty of Science; South Valley University, Qena, 83523,Egypt.
}

Received: 16 Oct. 2016

Accepted: 16 Nov. 2016

Available online: 25 Nov 2016

\section{Keywords}

- Growth factors

- Selenium,

- Streptozotocininduced diabetes,

- Steroidogenesis.

\begin{abstract}
Selenium ( $\mathrm{Se}$ ) is an essential trace element and found to have important roles in maintaining normal growth and reproduction. The effect of Se on testicular steroidogenesis and testicular expression of vascular endothelial growth factor (VEGF) and nerve growth factor-beta (NGF- $\beta$ ) was studied in streptozotocin (STZ)- induced diabetic rats. The study included 45 male albino rats randomly divided into 3 groups; control (group I, $n=15$ ), diabetic (group II, $\mathrm{n}=15$ ) and diabetic supplemented with Se (group III, $\mathrm{n}=15$ ). The investigation revealed that, diabetic group (group II) had a significant decrease in Se level and testicular steroidogenesis evidenced by the decrease in testosterone and in the activity of two important enzymes synthesizing testosterone 3-betahydroxysteroid dehydrogenase $(3 \beta-\mathrm{HSDH})$ and 17-beta-hydroxysteroid dehydrogenase (17ß$\mathrm{HSDH}$ ) compared to control group $(\mathrm{P}<0.05)$. In addition, there was a significant decrease in testicular tissue levels of VEGF and NGF- $\beta$ in diabetic rats compared to control rats $(\mathrm{P}<0.05)$. While, diabetic group supplemented with Se (group III) exhibited a significant increase in Se level, the activity of $3 \beta-\mathrm{HSDH}, 17 \beta-\mathrm{HSDH}$ and testosterone concentration compared to group II. Also, group III exhibited a significant increase in the testicular tissue levels of VEGF and NGF- $\beta$ compared to group II. In addition, Se supplementation improved testicular weight, the seminiferous tubules atrophy, the germinal epithelial cells lining tubules, Sertoli cells and interstitial cell of Leydig. In conclusion, Se supplementation increases testicular steroidogenesis and the expression of VEGF and NGF- $\beta$ in STZ-induced diabetic rats.
\end{abstract}




\section{Introduction}

Diabetes mellitus (DM) causes long-term damage, dysfunction, and failure of different organs. Disturbance in the male reproductive system is one of DM complications ${ }^{[1]}$. Testicular dysfunction, impotence, decreased fertility potential and retrograde ejaculations are conditions that have been described in diabetic males ${ }^{[2]}$. Clinical and experimental studies suggest that sperm parameters are altered in patients or animals with DM. The possible mechanisms involved in the onset of these alterations are hormonal changes, presence of neuropathy, and increased oxidative stress aspects present in patients with $\mathrm{DM}^{[3]}$.

Male fertility depends on proper testicular function. Testosterone production relies on the endocrine action of hormones released from the brain and testosterone acts locally in the testis to stimulate spermatogenesis. In addition, autocrineparacrine signaling of growth factors in the testis is essential for proper testis function ${ }^{[4]}$.

Selenium (Se) is an essential trace element present in a multitude of compounds named as selenoproteins. It is incorporated into proteins as selenocysteine. In the human genome, 25 genes for selenoproteins have been identified ${ }^{[5]}$. Glutathione peroxidases are selenoproteins protect against oxidative damage to spermatozoa throughout the process of sperm maturation. Mitochondrial glutathione peroxidase 4 (mGPx4), which is located to the midpiece compartment and constitutes up to $50 \%$ of the sperm midpiece protein content and the nucleus-associated glutathione peroxidase $4(\operatorname{snGPx} 4)$, serve as structural components of mature spermatozoa, ensuring viability of spermatozoa as well as providing protection against reactive oxygen species ${ }^{[6]}$. The testicular protective effect of Se appears to be mediated through its anti-apoptotic and antioxidative effects ${ }^{[7]}$. Supplementation of diabetic rats with $\mathrm{Se}$ was found to reduce insulin resistance and the activity of liver cytosolic protein tyrosine phosphatases, which are negative regulators of insulin signaling by about $50 \%{ }^{[8]}$. In addition, concentrations of selenium in tissues of diabetic rats were found lower than in non-diabetic control rats ${ }^{[9]}$.

Taking the above facts into consideration, the current Investigation was undertaken to evaluate the effect of Se on the diabetes-induced testicular changes in rats and the possible mechanism of its action.

\section{Materials and methods}

The study was approved by the Ethical Committee of Sohag University Hospital. All the procedures were carried out in accordance with the guidelines of the EU Directive 2010/63/EU for animal experiments.

\section{Experimental Design}

Forty five adult male Albino rats with average body weight of $200-250 \mathrm{~g}, 75$ - 90 days age obtained from the Animal Facility, Assuit University were included in the study. All animals were housed in metal shoe box cages $(20 \times 32 \times 20$ $\mathrm{cm}$ ) in Animal Facility, Sohag Faculty of Medicine at room temperature $\left(25-30^{\circ} \mathrm{C}\right)$ and normal lightdark cycle. Before study commencement; animals were adapted to diet and housing conditions for one week and had free access to standard 
laboratory chow and water during the study period. The animals were randomly divided into three groups, Group I: Control: daily orally administered physiological saline by gastric tube in a dose of 10 $\mu \mathrm{g} / 100 \mathrm{~g}$ body weight for 21 successive days, Group II: diabetic rats: diabetes was induced by intraperitoneal injection of single dose of STZ (60 $\mathrm{mg} / \mathrm{kg}$ body wt. in $0.01 \mathrm{~mol} / \mathrm{L}$ citrate buffer, $\mathrm{pH}$ 4.5). This dose of STZ caused hyperglycemia within 3 days, with fasting blood glucose levels over $200 \mathrm{mg} / \mathrm{dL}{ }^{[10]}$. The diabetic state was confirmed by daily measuring the fasting glucose level in the blood obtained from the tail vein. One day after the induction of diabetes, rats were daily orally received physiological saline by gastric tube in a dose of $10 \mu \mathrm{g} / 100 \mathrm{~g}$ body weight for 21 successive days. Group III: diabetic rats receiving Sodium Selenite. After induction of diabetes as in group II, Se was administered to group III. Sodium selenite was freshly dissolved in distilled water and given orally by gastric tube at a dose of $10 \mu \mathrm{g}$ sodium selenite/100 $\mathrm{g}$ body weight ${ }^{[11]}$ for 21 consecutive days. The last dose saline or Se was administered $12 \mathrm{~h}$ before the animals were anesthetized with ether for $5 \mathrm{~min}$. and killed via cardiac puncture.

\section{Preparation of Tissue Homogenate}

Rat testes were dissected out, weighed, and the tissue homogenate $10 \%(\mathrm{w} / \mathrm{v})$ was prepared from left testis of each rat in cold $0.1 \mathrm{~mol} / \mathrm{L}$ phosphate buffer, $\mathrm{pH} 7.4$ using a glass Teflon homogenizer. The homogenate was centrifuged at 14000xg in microcentrifuge for 15 minutes and the supernatants were collected and used for testosterone, enzymes activity and growth factors assay.

\section{Biochemical methods}

Assay of testosterone: Testicular testosterone was assayed using ELISA Kit (Cat.No. ABIN365714) according to the manufacture instructions.

Enzymes activity assay: For assaying the activities of $3 \beta-\mathrm{HSDH}$ and $17 \beta-\mathrm{HSDH}$, a reaction mixture containing $100 \mu \mathrm{mol}$ of sodium pyrophosphate buffer ( $\mathrm{pH}$ 9) and $0.5 \mu \mathrm{mol}$ of NAD for 3 3 -HSD and adenine dinucleotide phosphate NADPH for $17 \beta$-HSD, $0.08 \mu \mathrm{mol}$ of substrate (dehydroepiandrosterone for $3 \beta$-HSD and androstenedione for $17 \beta-\mathrm{HSD}$ ), and $100 \mu \mathrm{L}$ of the supernatant. The absorbance at $340 \mathrm{~nm}$ was measured at an interval of 20 seconds for 3 minutes using (UV)-VIS spectrophotometer ${ }^{[12]}$. Tissue protein concentration was assayed by lowery method ${ }^{[13]}$. The specific activities of the enzymes were expressed as nmol of NAD converted to $\mathrm{NADH} / \mathrm{mg}$ protein/min for $3 \beta-\mathrm{HSDH}$ or nmol of NADPH converted to NADP/mg protein/min for $17 \beta-H S D H$.

Growth factors levels assay: Vascular endothelial growth factor (VEGF) and nerve growth factor beta (NGF- $\beta$ ) levels were measured in testicular homogenate using rat specific ELISA kits (Rat VEGF ELISA Kit, RAB0512 Sigma and Rat $\beta$ NGF ELISA Kit RAB0381 Sigma, according to the manufacture instructions).

Selenium assay: Testicular tissue samples were wet-ashed with $16 \mathrm{~mol} / \mathrm{L}$ nitric acid evaporated and diluted with $0.1 \mathrm{~mol} / \mathrm{L}$ nitric acid, as described by Oteiza et al ${ }^{[14]}$. Se was assayed in samples using PERKIN-ELMER Flame atomic absorption spectrometer according to the manufacturer's instructions, and expressed as $\mu \mathrm{g} / \mathrm{mg}$ tissue. 


\section{Histopathology}

The right testis of each rat was dissected and cut in two halves across its longitudinal axis. Two (one gram) specimens were taken from the middle area of the parenchyma of each testis, fixed in Bouin's, processed for paraffin blocks and stained with heamatoxylin-eosin $(\mathrm{Hx} \quad \& \quad \mathrm{E})$ stain then histologically examined.

\section{Statistical analysis}

Data were expressed as mean $\pm \mathrm{SD}$ and analyzed using one way ANOVA test and Tukey's posttest. $\mathrm{P}$ - value $<0.05$ was considered statistically significant. All statistical calculations were performed using the computer program SPSS (Statistical Package for the Social Science; SPSS, Chicago, IL, USA) version 16 for Microsoft Windows, USA

\section{Results}

\section{Biochemical analyses}

Diabetic rats (group II) showed statistically significant $(\mathrm{P}<0.001)$ decrease in testicular weight $(1.244 \pm 0.016 \mathrm{gm})$ as compared with group I $(1.584 \pm 0.007 \mathrm{gm})$. Whereas selenium treatment to diabetic rats revealed restoring of testicular weight as evidenced by statistically nonsignificant difference between the weight of testes in group III $(1.569 \pm 0.016 \mathrm{gm})$ and group I. Regarding, Se level, it was significantly lower in group II (9 $\pm 2 \mu \mathrm{g} / \mathrm{g}$ tissue) compared to group I $(17.7 \pm 2.58 \mu \mathrm{g} / \mathrm{g}$ tissue $)$, while in group III (14.00 $\pm 2.25 \mu \mathrm{g} / \mathrm{g}$ tissue), it was significantly higher than in group II ( $\mathrm{P}<0.001)$. In addition, induction of diabetes to rats caused a significant decrease in steroidogenesis evidenced by the decrease in testosterone level $(0.153 \pm 0.025 \mathrm{ng} / \mathrm{mg}$ tissue in diabetic rats Vs. $0.35 \pm 0.027 \mathrm{ng} / \mathrm{mg}$ tissue in controls, $\mathrm{P}<0.0001$ ), and in the activity of two important enzymes synthesizing testosterone ( $3 \beta-$ HSDH and $17 \beta-\mathrm{HSDH})$. 3 $\beta$-HSDH level in group II was $20.40 \pm 2.8$ Vs $30.14 \pm 3.592$ nmol NAD reduced $/ \mathrm{min} / \mathrm{mg}$ protein in controls $(\mathrm{P}<0.0001)$. $17 \beta-\mathrm{HSDH}$ in diabetic rats was $25.2 \pm 2.5 \mathrm{Vs}$ $37.50 \pm 3.8 \mathrm{NADPH}$ oxidized $/ \mathrm{mg}$ protein $/ \mathrm{min}$ in controls $(\mathrm{P}<0.0001)$. Additionally a significant decrease in testicular tissue levels of VEGF and NGF- $\beta$ in diabetic rats was observed. VEGF level was $59.3 \pm 7.5 \mathrm{ng} / \mathrm{mg}$ protein in diabetic rats $\mathrm{Vs}$ $239.1 \pm 28.7 \mathrm{ng} / \mathrm{mg}$ protein in controls $(\mathrm{P}<$ $0.0001)$. NGF- $\beta$ level in diabetic rats was $13.87 \pm$ $2.6 \mathrm{ng} / \mathrm{mg}$ protein Vs $29.6 \pm 5.13 \mathrm{ng} / \mathrm{mg}$ protein in controls $(\mathrm{P}<0.0001)$. Group III exhibited a significant increase in testosterone level $(0.234 \pm$ $0.026 \mathrm{ng} / \mathrm{mg}$ tissue) compared to Group II (P < $0.05)$. Similarly, there were significant increases in $3 \beta$-HSDH, $17 \beta-$ HSDH, VEGF and NGF- $\beta$ (25.8 \pm $3.1,33 \pm 2.73,164.5 \pm 18.57,18.87 \pm 3.3$, respectively) in Group III compared to Group II (P $<0.05$ ) (figure $1 \mathrm{~b}-\mathrm{f}$ ).

\section{Histological examination of testicular tissue}

The histological examination of testicular tissue in different groups demonstrated that, in rats of group II, the germinal epithelial cells lining most of the seminiferous tubules were vacuolated with darkly stained nuclei and there were irregularities in the basal lamina of most of the tubules. Also, the normal organization of germinal epithelium was reduced and the cells of germinal epithelium had abnormal cellular attachment. The average numbers of different spermatogenic cells, Sertoli cells and Leydig cells were highly significantly reduced $(\mathrm{P}<0.001)$ when compared with $\mathrm{G} 1$. 
a
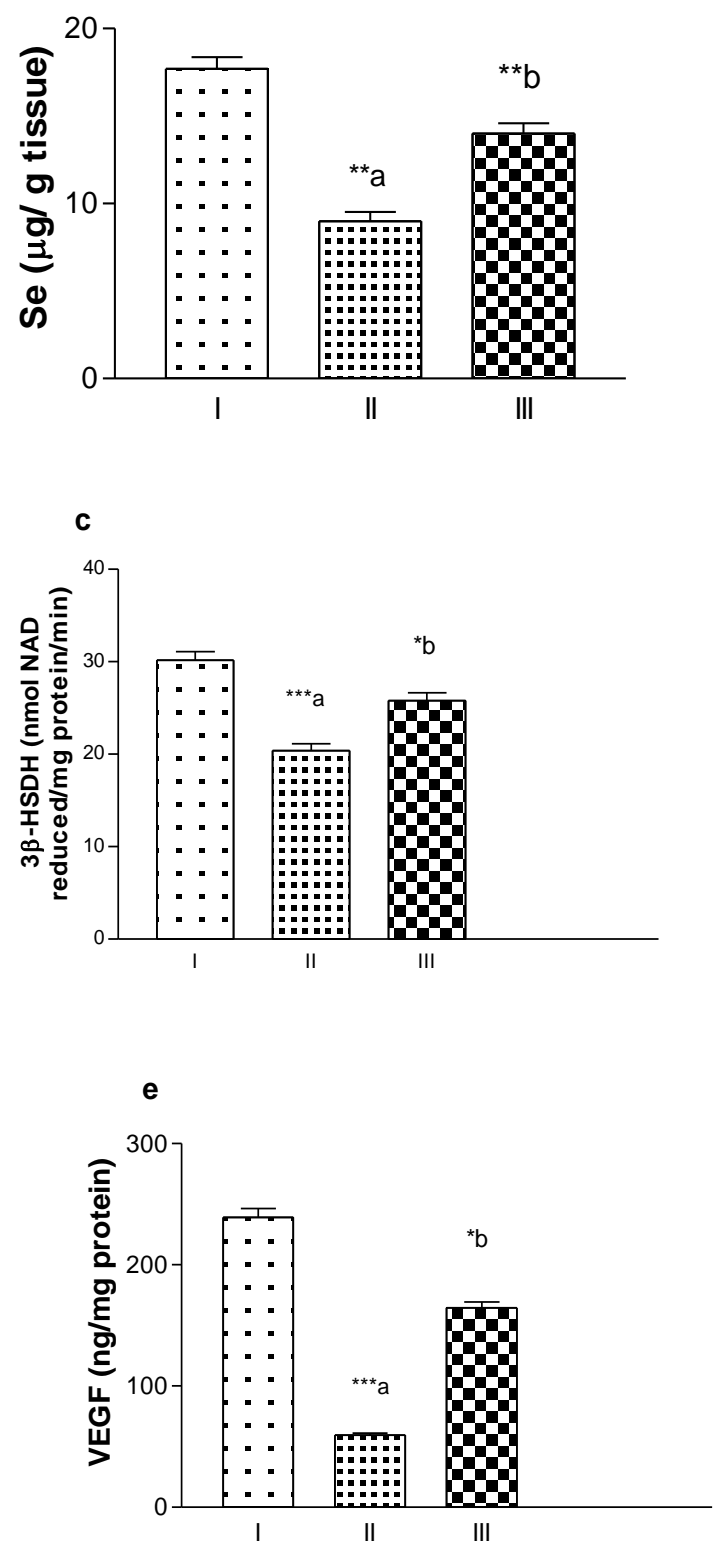

b

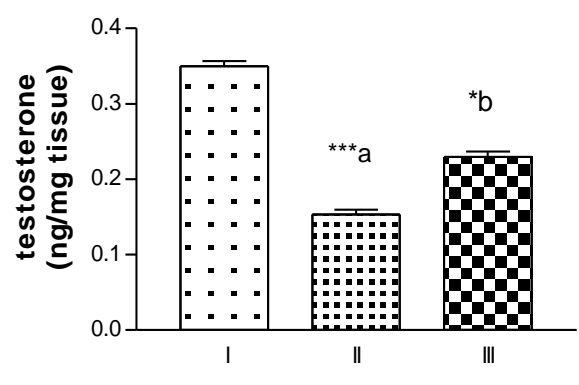

d
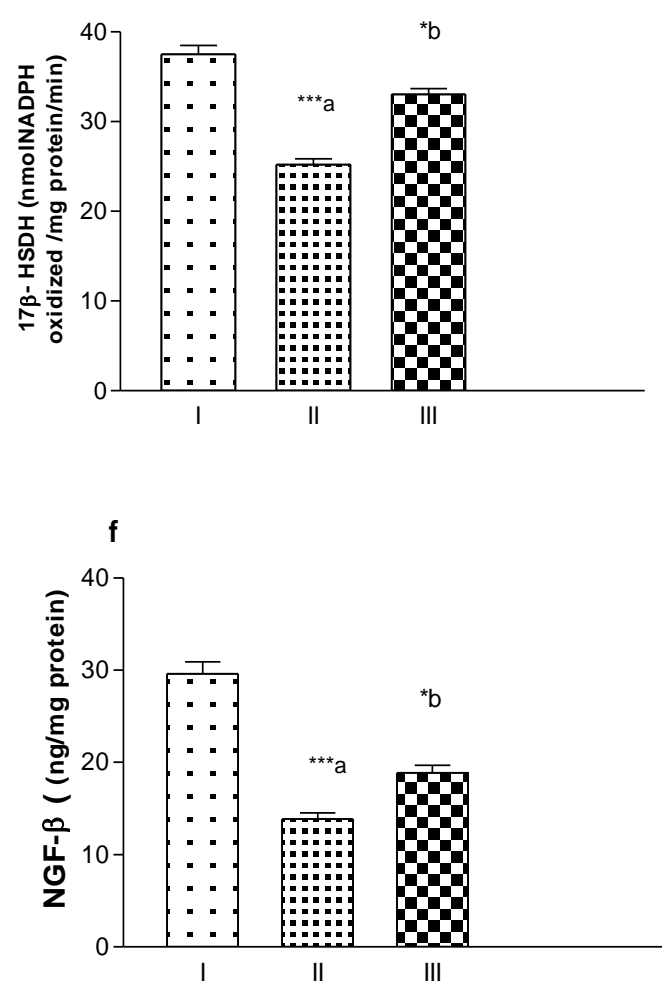

Figure (1): Mean $\pm \mathrm{SD}$ of the parameters measured in rat groups (I: control, II: diabetic, III: diabetic $+\mathrm{Se}$ ), ${ }^{* * *} \mathrm{P}<$ $0.0001,{ }^{* *} \mathrm{P}<0.001,{ }^{*} \mathrm{P}<0.05$, a, compared to control rats, b, compared to diabetic rats).

While, in diabetic rats supplemented with Se, the germinal epithelial cells lining the seminiferous tubules had no vacuolations and the germinal epithelium had more or less normal cellular attachment. The average numbers of spermatogenic cells, Sertoli cells and Leydig cells were non significantly differed from that of G1 (table 1, figure 2, 3\&4).

\section{Discussion}

This investigation revealed deteriorating effects of STZ-induced diabetes on the testes of male albino rats as evidenced by a decrease in; average testicular weight, testicular Se level, testicular

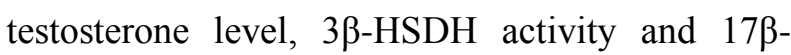
HSDH activity in STZ-induced diabetic rats compared to control rats. 
Table (1): Statistical evaluation of the average testicular weights and mean numbers \pm SE of different types of spermatogenic cells, Sertoli cells and Leydig cells in the testes of adult rats of control, DM and DM + Se groups:

\begin{tabular}{|l|c|c|c|}
\hline \multicolumn{1}{|c|}{ Groups } & Control & DM & DM \& SE \\
\hline Testes weights $(\mathbf{g m})$ & $1.584 \pm 0.007$ & $1.244 \pm 0.016 *$ & $1.569 \pm 0.016, \mathbf{N S}$ \\
\hline Spermatogenic cells & $21.00 \pm 0.436$ & $14.86 \pm 0.508 *$ & $20.43 \pm 0.429, \mathbf{N S}$ \\
\hline Spermatogonia & $66.43 \pm 0.481$ & $61.29 \pm 0.286 *$ & $65.86 \pm 0.404, \mathbf{N S}$ \\
\hline Spermatocytes & $97.57 \pm 0.202$ & $93.29 \pm 0.286 *$ & $97.29 \pm 0.360, \mathbf{N S}$ \\
\hline Spermatids & $44.86 \pm 0.261$ & $40.29 \pm 0.286 *$ & $44.00 \pm 0.436, \mathbf{N S}$ \\
\hline Sperms & $14.71 \pm 0.286$ & $11.00 \pm 0.218 *$ & $14.43 \pm 0.202, \mathbf{N S}$ \\
\hline Sertoli cells & $3.143 \pm 0.261$ & $1.429 \pm 0.202 *$ & $2.857 \pm 0.261, \mathbf{N S}$ \\
\hline Leydig cells &
\end{tabular}

$P<0.0001$, NS: statistically non significant, compared to control group
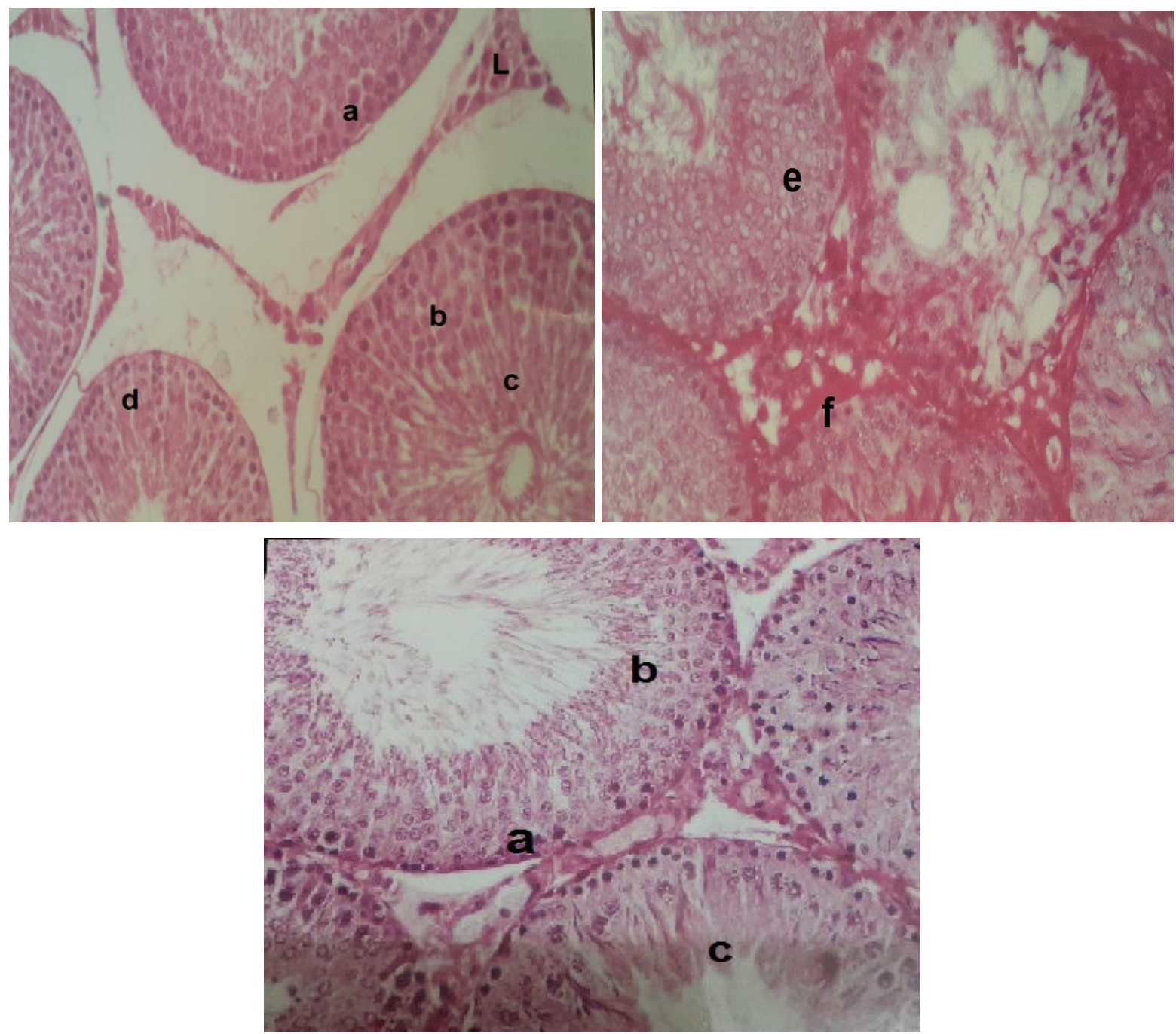

Figure (2): Photomicrographs of a testis of control group (A) showing :(a) germ cells, (b) lining germinal epithelium of different stages ,(c) sperm filled seminiferous tebular lumen, (d) supporting sertoli cells and (L) Leydig cells, of diabetes group (B) showing (e) the germinal epithelial cells lining most of the tubules are vacuolated and darkly stained nuclei .Note, the irregularities in the basal lamina of most of the tubules (f) and of selenium treated testis showing (a) germ cells, (b) lining germinal epithelium of different stages and (c) sperms in the seminiferous tubules. (Hx \& E x200). 
In addition, a significant decrease in VEGF, NGF$\beta$ and deterioration in the testicular seminiferous tubules with significant decrease in the average numbers of different spermatogenic cells, Sertoli cells and Leydig cells when compared to group I. In diabetic rats supplemented with Se, the activity of $3 \beta$-HSDH, $17 \beta$-HSDH and testosterone concentration were significantly higher than in diabetic rats non-supplemented with Se. Also, significant increase in the testicular tissue levels of VEGF and NGF- $\beta$ was observed in diabetic rats supplemented with Se. In addition, Se supplementation improved the seminiferous tubules atrophy, the germinal epithelial cells lining tubules and increased the average numbers of spermatogenic cells, Sertoli cells and Leydig cells. Previous studies reported a decrease in Se level in tissues of diabetic rats and selenium mediates a number of insulin like actions both in vivo and in vitro, such as stimulating glucose uptake and regulating metabolic processes, including glycolysis, gluconeogenesis, fatty acid synthesis and the pentose phosphate pathway $[9,15] .3 \beta-$ HSDH and $17 \beta-H S D H$ play essential roles in steroidogenesis. These enzymes catalyze the final step in the biosynthesis of active gonadal steroid hormones, estradiol, and testosterone ${ }^{[16]}$. STZinduced diabetes was reported to be associated with a decrease in Leydig cell function and testosterone production due to the absence of the stimulatory effect of insulin on these cells and a decrease in FSH and LH levels. The decrease in FSH was also accompanied by a decrease in seminiferous tubules FSH receptors and a significantly diminished response of tubular epithelium to FSH stimulation ${ }^{[17]}$. A decrease in testicular tissue levels of VEGF, NGF- $\beta$ in diabetic rats was previously reported ${ }^{[18]}$. VEGF is an angiogenic factor and has a role in endothelial and neuronal cell survival. VEGF is important for spermatogenesis and its receptors were found located on interstitial cells and seminiferous tubules ${ }^{[19]}$. VEGF supports proliferation of germ cells and inhibits its apoptosis ${ }^{[20] . ~ I n ~ a d d i t i o n, ~}$ VEGF facilitates the transport of endocrine hormones, nutrition and oxygen, regulates microcirculation and modulates endothelial permeability in testis ${ }^{[21,22]}$. NGF- $\beta$ is found in the nervous system and in testicular tissue and involved in sperm development ${ }^{[23]}$. High levels of NGF- $\beta$ aid in sperm maturation as found in epididymal head and body and the decrease in NGF- $\beta$ level may result from germ cell atrophy ${ }^{[24]}$. In addition, Sertoli cells, spermatocytes, and early spermatids are known to synthesize NGF- $\beta{ }^{[25]}$, which is involved in sperm motility and acrosome reaction ${ }^{[26]}$. Selenium supplementation enhanced the STZ-induced reduction in the activities of antioxidant enzymes, decreased the serum glucose, glycated hemoglobin content, concentration of high-sensitivity C-reactive protein, lipid peroxidation products and inflammatory mediators. Decrease in the phospholipase activity by selenium supplementation also contributed to the downregulation of leukotriene pathway. It also downregulated the expressions of nuclear transcription factor $\kappa \mathrm{B}(\mathrm{NF} \kappa \mathrm{B})$, lipoxygenase, cyclooxygenase, 5-lipoxygenase-activating protein, and receptor for leukotriene B4. Hence, selenium decreased the production of reactive oxygen species and inhibited the activation of NFкB-mediated transcription of pro-inflammatory mediators [27]. Deficiency in dietary selenium decreases the reproductive potential of male mice 
and is associated with oxidative damage in spermatozoa ${ }^{[28]}$. Sodium selenite and zinc sulfate supplementation significantly protected against exercise-induced testicular gamatogenic and spermatogenic disorders, prevented testicular oxidative stress, and increased antioxidant status ${ }^{\text {[29] }}$. The consumption of Se-deficient diets in farm animals was associated with decreased fertility and growth retardation ${ }^{[30]}$. Male gonads tend to accumulate Se as pubertal maturation begins and oligospermia, increase in abnormal spermatozoa, and a decline in the ratio of motile to immotile spermatozoa were reported in Se-deficient rats ${ }^{[31]}$. Testosterone secretion is affected by Se deficiency as its deficiency causes changes in the LH receptors of Leydig cells. The bulbourethral and prostate glands, and the caput and corpus epididymis have shown as examples of the organs with the highest Se retention ${ }^{[30]}$. In conclusion, this study demonstrated that Se increased testicular steroidogenesis through increasing the activity of 3 $\beta$-HSDH and $17 \beta$-HSDH. In addition, it improved the histological picture the testis and increased the expression of VEGF and NGF- $\beta$ in STZ-induced diabetic rats.

\section{Conflict of interest}

None

\section{REFERENCES}

1. Ding, G.L., Liu, Y., Liu, M.E. , Pan, J.X., Guo, M.X., Sheng, J.Z., Huang, H.F.. The effects of diabetes on male fertility and epigenetic regulation during spermatogenesis. Asian J. Androl, 17: 948-953, 2015.

2. Amaral,S., Oliveira, P.J., Ramalho-Santos, J. Diabetes and the impairment of reproductive function: possible role of mitochondria and reactive oxygen species. Curr Diabetes Rev. 4 : 46-54, 2008.

3. La Vignera, S., Condorelli, R., Vicari, E, D'Agata, R. , Calogero, A.E. Diabetes Mellitus and Sperm Parameters. J. Androl 33: 145-153, 2015.

4. Griffeth, R.J., Bianda, V., Nef, S. The emerging role of insulin-like growth factors in testis development and function. Basic Clin. Androl. 24 : 12, 2014.

5. Kipp, A. P., Strohm, D. Brigelius-Flohé, R., Schomburg, L. , Bechthold, A. , LeschikBonnet, E., Heseker, H. Revised reference values for selenium intake. J. Trace Elem. Med. Biol. 32 : 195-199, 2015.

6. Ahsan,A., Kamran, Z. , Raza, I., Ahmad, S. , Babar, W., Riaz, M.H. , Iqbal, Z. Role of selenium in male reproduction-A review. Animal Reproduction Science 146 : 55-62, 2014

7. Kara, O. , Sari, E. , Akşit, H. , Yay, A. , Akşit, D. , Dönmez, M. I. Effects of selenium on ischaemia-reperfusion injury in a rat testis model. Andrologia

(2016) doi:10.1111/and.12571.

8. Mueller AS, Pallauf J: Compendium of the antidiabetic effects of supranutritionalselenate doses: in vivo and in vitro investigationswith type II diabetic db/db mice.J Nutr Biochem 17:548 -560, 2006.

9. Ulas M. Effect of vitamin E on trace element levels in various tissues of diabetic rats. Trace Elements \& Electrolytes 29: 154-161, 2012.

10. Naziroğlu, M. Enhanced Testicular Antioxidant Capacity in StreptozotocinInduced Diabetic Rats. Protective Role of 
Vitamins $\mathrm{C}$ and $\mathrm{E}$ and Selenium. Biol. Trace Elem. Res 94 : 61-71, 2003.

11. Seema, P. , Swathy, S.S. , Indira, M. Protective Effect of Selenium on NicotineInduced Testicular Toxicity in Rats. Biol Trace Elem Res 120: 212-218, 2007.

12. Bergmeyer, H.U., Grassl, M., Walter, H.E. Methods of Enzymatic Analysis. Vol 2. 3rd ed. Deerfield Beach, FL: Verlag Chemie; 1983.

13. Lowry, O.H. , Rosebrough , N.J., Farr A.L. et al.. Protein measurement with the Folin phenol reagent. J Biol Chem 193 : 265$275,1951$.

14. Oteiza, P. I., Olin, K. L., Fraga, C. G. \& Keen, C. L. Zinc deficiency causes oxidative damage to proteins, lipids and DNA in rat testes. J. Nutr. 125: 823-829, 1995.

15. Kamal M, Salem M, Kholousi N, Ashmawy K. Evaluation of trace elements and Malondialdehyde levels in type II diabetes mellitus Diabetes \& Metabolic Syndrome. Clinical Research \& Reviews. 3:214-218, 2009.

16. Payne A.H. and Hales, D. B. Overview of Steroidogenic Enzymes in the Pathway from Cholesterol to Active Steroid Hormone. Endocrine Reviews 25 (2004) 947-970.

17. Ballester, J., Muñoz, M.C., Domínguez, J., Rigau, T., Guinovart, J.J., Rodríguez-Gil, J.E. Insulin-dependent diabetes affects testicular function by FSH- and LH-linked mechanisms. J. Androl. 25 : 706-19, 2004.

18. Sisman, A. R., Kiray, M., Camsari, U. M. et al., Potential Novel Biomarkers for Diabetic Testicular Damage in Streptozotocin-Induced Diabetic Rats: Nerve Growth Factor Beta and
Vascular Endothelial Growth Factor, Disease Markers, v (2014) Article ID 108106, 7 pages, 2014. doi:10.1155/2014/108106.

19. Bott, R. C., McFee, R. M., Clopton, D. T., Toombs, C., and Cupp, A. S. Vascular endothelial growth factor and kinase domain region receptor are involved in both seminiferous cord formation and vascular development during testis morphogenesis in the rat. Biol. Reprod. 75 : 56-67, 2006.

20. Caires, K. C., De Avila, J. , McLean, D. J. Vascular endothelial growth factor regulates germ cell survival during establishment of spermatogenesis in the bovine testis. Reproduction 138 : 667-677, 2009.

21. Kilic, S., Lortlar, N., Bardakci Y. et al., Caspase-3 and VEGF immunopositivity in seminiferous tubule germ cells in cases of obstructive and non-obstructive azoospermia in smokers versus non-smokers. J. Assis. Reprod Genetics 26 : 57-63, 2009.

22. Tunc kiran, A., Ayan, S. C , Bozlu, M., Yilmaz, N., Acar, D. and Akbay, E. Protective effect of vascular endothelial growth factor on histologic changes in testicular ischemia-reperfusion injury. Fertility and Sterility 84 : 468-473, 2005.

23. Djakiew, D., Pflug, B., Dionne, C. and Onoda, M. Postnatal expression of nerve growth factor receptors in the rat testis. Biol. Reprod. 51 :214-221, 1994.

24. Nylen, P., Ebendal, T., Eriksdotter-Nilsson M. et al., Testicular atrophy and loss of nerve growth factor-immunoreactive germ cell line in rats exposed to $\mathrm{n}$-hexane and a protective effect of simultaneous exposure to toluene or xylene. Arch. Toxicol 63 : 296-307, 1989 
25. Ayer-LeLievre, C., Olson, L., Ebendal, T., Hallbook, F. and Persson, H. Nerve growth factor mRNA and protein in the testis and epididymis of mouse and rat. Proc. Nat. Acad. Sci. USA 85 :2628-2632, 1988.

26. Jin, W., Tanaka, A. , Watanabe, G., Matsuda, H. and Taya, K. Effect of NGF on the motility and acrosome reaction of golden hamster spermatozoa in vitro, J. Reprod. Develop. 56 : 437-443, 2010.

27. Dhanya BL, Swathy RP, Indira M.Selenium downregulates oxidative stress-induced activation of leukotriene pathway in experimental rats with diabetic cardiac hypertrophy. Biol Trace Elem Res. 161 : 10715, 2014.

28. Sánchez-Gutiérrez, M., García-Montalvo, E. A. , Izquierdo-Vega, J. A., Del Razo, L. M. Effect of dietary selenium deficiency on the in vitro fertilizing ability of mice spermatozoa. Cell Biol Toxicol 24 : 321-329, 2008.

29. Jana, K., Samanta, P.K., Manna, I. , Ghosh, P., Singh, N., Khetan, R. P., Ray, B. R. Protective effect of sodium selenite and zinc sulfate on intensive swimming-induced testicular gamatogenic and steroidogenic disorders in mature male rats. Applied Physiol, Nutr. Metabol. 33 : 903-914, 2008.

30. Pal, A. Role of Copper and Selenium in Reproductive Biology: A Brief Update. Biochem Pharmacol (Los Angel) 4 (2015) 181. doi:10.4172/2167-0501.1000181

31. Behne D, Höfer T, von Berswordt-Wallrabe $\mathbf{R}$, Elger W. Selenium in the testis of the rat: studies on its regulation and its importance for the organism. J Nutr $112: 1682-1687,1982$. 